\title{
Original Research \\ Adsorption Kinetics of Lead and Zinc Ions by Coffee Residues
}

\author{
Chung-Hsin Wu*, Chao-Yin Kuo², Shu-Shian Guan ${ }^{3}$ \\ 'Department of Chemical and Materials Engineering, National Kaohsiung University of Applied Sciences, \\ 415 Chien Kung Road, Kaohsiung, Taiwan \\ ${ }^{2}$ Department of Environmental and Safety Engineering, National Yunlin University of Science and Technology, \\ 123 University Road, Sec. 3, Douliou, Yunlin, Taiwan \\ ${ }^{3}$ Department of Environmental Engineering, Da-Yeh University, Da-Tsuen, Chang-Hua, Taiwan
}

Received: 16 July 2014

Accepted: 23 September 2014

\begin{abstract}
Untreated coffee residues (UCRs) were used to remove heavy metal ions from aqueous solutions. The effects of solution $\mathrm{pH}$, heavy metal ions, and UCR concentrations on heavy metal ion removal by UCRs were determined. The removal percentage for heavy metal ions increased as $\mathrm{pH}$ and UCR doses increased; conversely, it decreased as the concentration of heavy metal ions increased. This study employed the pseudo firstand second-order kinetics models, the intraparticle diffusion model, and the Bangham model to simulate adsorption kinetics of $\mathrm{Pb}^{2+}$ and $\mathrm{Zn}^{2+}$ onto UCRs. Simulation results indicate that adsorption kinetics fit well with the pseudo second-order model. After reaction for $180 \mathrm{~min}$ at [adsorbate] $=20 \mathrm{mg} / \mathrm{L},[\mathrm{UCRs}]=2 \mathrm{~g} / \mathrm{L}$, and $\mathrm{pH} 5$, the adsorption percentage of $\mathrm{Pb}^{2+}$ and $\mathrm{Zn}^{2+}$ was $96 \%$ and $44 \%$, respectively; moreover, the adsorption density of $\mathrm{Pb}^{2+}$ and $\mathrm{Zn}^{2+}$ onto UCRs was 9.7 and $4.4 \mathrm{mg} / \mathrm{g}\left(4.7 \times 10^{-2}\right.$ and $\left.6.8 \times 10^{-2} \mathrm{mmol} / \mathrm{g}\right)$, respectively. The adsorption of $\mathrm{Pb}^{2+}$ and $\mathrm{Zn}^{2+}$ onto UCRs is controlled mainly by surface diffusion.
\end{abstract}

Keywords: adsorption, coffee residues, kinetics

\section{Introduction}

Mining, electroplating, and metal processing are the main sources of heavy metal contamination. Metals such as lead, arsenic, chromium, mercury, copper, and zinc have been characterized as hazardous heavy metals. Due to their hazardous effects, persistency, and tendency to accumulate, effective removal of heavy metal ions from wastewater is an important issue.

Various agricultural by-products have been used to remove heavy metals from solutions. Using waste materials as low-cost adsorbents is attractive as it reduces costs for their disposal. Several studies have employed low-cost adsorbents such as orange peels [1], coffee husks [2], cof-

*e-mail: wuch@kuas.edu.tw fee residues/clay [3], coffee grounds [4, 5], sugar beet pulp $[6]$, tea leaves $[4,7]$, rice hulls $[8], \gamma-\mathrm{Al}_{2} \mathrm{O}_{3}[9], \mathrm{Fe}(\mathrm{OH})^{3}$ [10], and black gram husks [11] to remove $\mathrm{Zn}^{2+}$ from aquatic solutions. Additionally, $\mathrm{Pb}^{2+}$ has been removed from solutions by coffee residues/clay [3], coffee grounds [4, 5, 12], sugar beet pulp [6], tea leaves [4, 7, 13], rice husk ash [14], grape stalks [15], treated human hair [16], and black gram husks [11]. The adsorption kinetics of $\mathrm{Cu}^{2+}[2,17], \mathrm{Ni}^{2+}$ [17], $\mathrm{Cd}^{2+}[2,18], \mathrm{Pb}^{2+}[12], \mathrm{Zn}^{2+}$ [2], and $\mathrm{Cr}^{6+}$ [2] were reported for adsorption onto coffee residues. However, only pseudo first- and second-order models were tested for adsorption kinetics in these investigations. Generally, an adsorption process can be characterized as three stages:

(i) external diffusion or boundary-layer diffusion,

(ii) intraparticle mass diffusion,

(iii) adsorption on interior sites. 
Table 1. Kinetic parameters for the removal of $\mathrm{Pb}^{2+}$ and $\mathrm{Zn}^{2+}$ by UCRs $\left(\mathrm{T}=25^{\circ} \mathrm{C}\right)$.

\begin{tabular}{|c|c|c|c|c|}
\hline Pseudo first-order model & $\mathrm{q}_{\mathrm{e}, \text { exp }}(\mathrm{mg} / \mathrm{g})$ & $\mathrm{k}_{1}(1 / \mathrm{min})$ & $\mathrm{q}_{\mathrm{e}, \text { cal }}(\mathrm{mg} / \mathrm{g})$ & $\mathrm{R}^{2}$ \\
\hline \multirow{2}{*}[\mathrm{Pb}^{2+}]{$=20 \mathrm{mg} / \mathrm{L},[\mathrm{UCRs}]=2 \mathrm{~g} / \mathrm{L}, \mathrm{pH}=5$} & 9.7 & \multirow{2}{*}{$6.7 \times 10^{-3}$} & 5.3 & \multirow{2}{*}{0.977} \\
\hline & $\left(4.7 \times 10^{-2}\right)$ & & $\left(2.6 \times 10^{-2}\right)$ & \\
\hline \multirow{2}{*}[\mathrm{Pb}^{2+}]{$=80 \mathrm{mg} / \mathrm{L},[\mathrm{UCRs}]=2 \mathrm{~g} / \mathrm{L}, \mathrm{pH}=5$} & 25.5 & \multirow{2}{*}{$1.9 \times 10^{-2}$} & 22.8 & \multirow{2}{*}{0.994} \\
\hline & $\left(1.2 \times 10^{-1}\right)$ & & $\left(1.1 \times 10^{-1}\right)$ & \\
\hline \multirow{2}{*}[\mathrm{Pb}^{2+}]{$=20 \mathrm{mg} / \mathrm{L},[\mathrm{UCRs}]=1 \mathrm{~g} / \mathrm{L}, \mathrm{pH}=5$} & 13.3 & \multirow{2}{*}{$1.3 \times 10^{-2}$} & 10.4 & \multirow{2}{*}{0.997} \\
\hline & $\left(6.4 \times 10^{-2}\right)$ & & $\left(5.0 \times 10^{-2}\right)$ & \\
\hline \multirow{2}{*}[\mathrm{Pb}^{2+}]{$=20 \mathrm{mg} / \mathrm{L},[\mathrm{UCRs}]=2 \mathrm{~g} / \mathrm{L}, \mathrm{pH}=3$} & 6.9 & \multirow{2}{*}{$1.6 \times 10^{-2}$} & 6.0 & \multirow{2}{*}{0.999} \\
\hline & $\left(3.3 \times 10^{-2}\right)$ & & $\left(2.9 \times 10^{-2}\right)$ & \\
\hline \multirow{2}{*}[\mathrm{Zn}^{2+}]{$=20 \mathrm{mg} / \mathrm{L},[\mathrm{UCRs}]=2 \mathrm{~g} / \mathrm{L}, \mathrm{pH}=5$} & 4.4 & \multirow{2}{*}{$1.8 \times 10^{-2}$} & 3.9 & \multirow{2}{*}{0.949} \\
\hline & $\left(6.8 \times 10^{-2}\right)$ & & $\left(6.0 \times 10^{-2}\right)$ & \\
\hline Pseudo second-order model & $\mathrm{q}_{\mathrm{e}, \exp }(\mathrm{mg} / \mathrm{g})$ & $\mathrm{k}_{2}$ (g/mg.min) & $\mathrm{q}_{\mathrm{e}, \mathrm{cal}}(\mathrm{mg} / \mathrm{g})$ & $\mathrm{R}^{2}$ \\
\hline \multirow{2}{*}[\mathrm{Pb}^{2+}]{$=20 \mathrm{mg} / \mathrm{L},[\mathrm{UCRs}]=2 \mathrm{~g} / \mathrm{L}, \mathrm{pH}=5$} & 9.7 & \multirow{2}{*}{$9.7 \times 10^{-3}$} & 9.5 & \multirow{2}{*}{0.990} \\
\hline & $\left(4.7 \times 10^{-2}\right)$ & & $\left(4.6 \times 10^{-2}\right)$ & \\
\hline \multirow{2}{*}[\mathrm{Pb}^{2+}]{$=80 \mathrm{mg} / \mathrm{L},[\mathrm{UCRs}]=2 \mathrm{~g} / \mathrm{L}, \mathrm{pH}=5$} & 25.5 & \multirow{2}{*}{$9.5 \times 10^{-4}$} & 26.3 & \multirow{2}{*}{0.993} \\
\hline & $\left(1.2 \times 10^{-1}\right)$ & & $\left(1.3 \times 10^{-1}\right)$ & \\
\hline \multirow{2}{*}[\mathrm{Pb}^{2+}]{$=20 \mathrm{mg} / \mathrm{L},[\mathrm{UCRs}]=1 \mathrm{~g} / \mathrm{L}, \mathrm{pH}=5$} & 13.3 & \multirow{2}{*}{$1.0 \times 10^{-2}$} & 12.0 & \multirow{2}{*}{0.994} \\
\hline & $\left(6.4 \times 10^{-2}\right)$ & & $\left(5.8 \times 10^{-2}\right)$ & \\
\hline \multirow{2}{*}[\mathrm{Pb}^{2+}]{$=20 \mathrm{mg} / \mathrm{L},[\mathrm{UCRs}]=2 \mathrm{~g} / \mathrm{L}, \mathrm{pH}=3$} & 6.9 & \multirow{2}{*}{$1.1 \times 10^{-2}$} & 6.8 & \multirow{2}{*}{0.997} \\
\hline & $\left(3.3 \times 10^{-2}\right)$ & & $\left(3.3 \times 10^{-2}\right)$ & \\
\hline \multirow{2}{*}[\mathrm{Zn}^{2+}]{$=20 \mathrm{mg} / \mathrm{L},[\mathrm{UCRs}]=2 \mathrm{~g} / \mathrm{L}, \mathrm{pH}=5$} & 4.4 & \multirow{2}{*}{$2.1 \times 10^{-2}$} & 4.6 & \multirow{2}{*}{0.999} \\
\hline & $\left(6.8 \times 10^{-2}\right)$ & & $\left(7.0 \times 10^{-2}\right)$ & \\
\hline Intraparticle diffusion model & $\mathrm{k}_{\mathrm{i}}(\mathrm{mg} /$ & & $\mathrm{C}(\mathrm{mg} / \mathrm{g})$ & $\mathrm{R}^{2}$ \\
\hline$\left[\mathrm{Pb}^{2+}\right]=20 \mathrm{mg} / \mathrm{L},[\mathrm{UCRs}]=2 \mathrm{~g} / \mathrm{L}, \mathrm{pH}=5$ & & & 5.35 & 0.926 \\
\hline$\left[\mathrm{Pb}^{2+}\right]=80 \mathrm{mg} / \mathrm{L},[\mathrm{UCRs}]=2 \mathrm{~g} / \mathrm{L}, \mathrm{pH}=5$ & & & -5.70 & 0.973 \\
\hline$\left[\mathrm{Pb}^{2+}\right]=20 \mathrm{mg} / \mathrm{L},[\mathrm{UCRs}]=1 \mathrm{~g} / \mathrm{L}, \mathrm{pH}=5$ & & & 4.79 & 0.989 \\
\hline$\left[\mathrm{Pb}^{2+}\right]=20 \mathrm{mg} / \mathrm{L},[\mathrm{UCRs}]=2 \mathrm{~g} / \mathrm{L}, \mathrm{pH}=3$ & & & -0.38 & 0.992 \\
\hline$\left[\mathrm{Zn}^{2+}\right]=20 \mathrm{mg} / \mathrm{L},[\mathrm{UCRs}]=2 \mathrm{~g} / \mathrm{L}, \mathrm{pH}=5$ & & & 0.87 & 0.980 \\
\hline Bangham model & & & $\mathrm{k}_{0}(\mathrm{l} /(\mathrm{mg} / \mathrm{l}))$ & $\mathrm{R}^{2}$ \\
\hline$\left[\mathrm{Pb}^{2+}\right]=20 \mathrm{mg} / \mathrm{L},[\mathrm{UCRs}]=2 \mathrm{~g} / \mathrm{L}, \mathrm{pH}=5$ & & & $7.8 \times 10^{-2}$ & 0.924 \\
\hline$\left[\mathrm{Pb}^{2+}\right]=80 \mathrm{mg} / \mathrm{L},[\mathrm{UCRs}]=2 \mathrm{~g} / \mathrm{L}, \mathrm{pH}=5$ & & & $1.1 \times 10^{-2}$ & 0.962 \\
\hline$\left[\mathrm{Pb}^{2+}\right]=20 \mathrm{mg} / \mathrm{L},[\mathrm{UCRs}]=1 \mathrm{~g} / \mathrm{L}, \mathrm{pH}=5$ & & & $1.9 \times 10^{-2}$ & 0.922 \\
\hline$\left[\mathrm{Pb}^{2+}\right]=20 \mathrm{mg} / \mathrm{L},[\mathrm{UCRs}]=2 \mathrm{~g} / \mathrm{L}, \mathrm{pH}=3$ & & & $2.0 \times 10^{-2}$ & 0.995 \\
\hline$\left[\mathrm{Zn}^{2+}\right]=20 \mathrm{mg} / \mathrm{L},[\mathrm{UCRs}]=2 \mathrm{~g} / \mathrm{L}, \mathrm{pH}=5$ & & & $1.5 \times 10^{-2}$ & 0.951 \\
\hline
\end{tabular}

(): value in $\mathrm{mmol} / \mathrm{g}$

However, pseudo first- and second-order models cannot apply to fit the experimental results to examine the mechanism of adsorption of heavy metals onto adsorbents. Moreover, no study has clearly provided kinetics model analyses of adsorption of $\mathrm{Pb}^{2+}$ and $\mathrm{Zn}^{2+}$ onto untreated coffee residues (UCRs). Hence, this work applied pseudo firstand second-order models, the intraparticle diffusion model, and the Bangham model to simulate the adsorption kinetics of $\mathrm{Pb}^{2+}$ and $\mathrm{Zn}^{2+}$ onto UCRs. Study objectives were:

(i) to assess the effectiveness of $\mathrm{Pb}^{2+}$ and $\mathrm{Zn}^{2+}$ removal while varying solution $\mathrm{pH}$, heavy metal ion concentrations, and UCRs concentrations;

(ii) to provide parameters and adsorption-controlled mechanism for adsorption kinetics of $\mathrm{Pb}^{2+}$ and $\mathrm{Zn}^{2+}$ onto UCRs. 


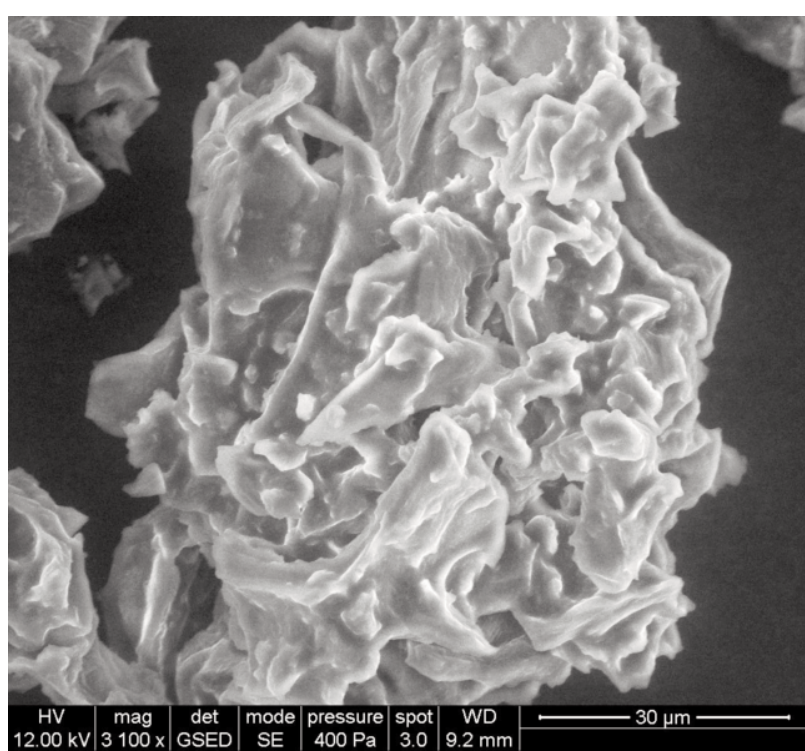

Fig. 1. SEM micrograph of UCRs.

\section{Materials and Methods}

\section{Materials}

The UCRs were obtained from a local manufacturer after steam extraction from coffee grounds for the manufacture of instant coffee. The UCRs were dried at $50^{\circ} \mathrm{C}$ for $48 \mathrm{~h}$ and then passed through a 100-mesh sieve. The $\mathrm{Pb}\left(\mathrm{NO}_{3}\right)_{2}, \mathrm{Zn}\left(\mathrm{NO}_{3}\right)_{2}, \mathrm{HNO}_{3}$, and $\mathrm{NaOH}$ were purchased from Merck. Solution $\mathrm{pH}$ was adjusted by adding $\mathrm{HNO}_{3}$ and $\mathrm{NaOH}$. All compounds were used as received and all solutions were prepared using Milli-Q deionized water and reagent-grade chemicals.

\section{Experimental Methods}

The morphology of UCRs was examined by scanning electron microscopy (SEM) (JEOL JSM-6500F, Japan), the specific surface area was determined by the BET method with a surface area analyzer (ASAP 2010; Micromeritics, USA), and surface potential was assessed by a Zeta-Meter 3.0 (Zeta-Meter, Inc., USA).

All adsorption experiments were conducted in a closed $250 \mathrm{~mL}$ pyramidal glass bottle. Adsorption was determined over $3 \mathrm{~h}$ at $25^{\circ} \mathrm{C}$. Initial $\mathrm{pH}$ was 5.0 in all adsorption experiments, except for experiments assessing the effect of $\mathrm{pH}$. In total, $0.4 \mathrm{~g}$ UCRs were placed in a bottle containing 200 $\mathrm{mL}$ heavy metal solution at $20 \mathrm{mg} / \mathrm{L}$, and the bottle was then shaken at $100 \mathrm{rpm}$. The effect of heavy metal concentration on heavy metal removal by UCRs was investigated by using heavy metal concentrations of 20 and $80 \mathrm{mg} / \mathrm{L}$ at [UCRs] $=2 \mathrm{~g} / \mathrm{L}$. The effect of UCR dosage on heavy metal removal was studied at UCR concentrations of 1 and $2 \mathrm{~g} / \mathrm{L}$ at $[$ heavy metal] $=20 \mathrm{mg} / \mathrm{L}$. The effect of $\mathrm{pH}$ on heavy metal removal by UCRs was studied with initial $\mathrm{pH}$ values of 3 and 5 at [heavy metal] $=20 \mathrm{mg} / \mathrm{L}$ and [UCRs] $=2 \mathrm{~g} / \mathrm{L}$. Suspended particles were separated by filtration through a $0.22 \mu \mathrm{m}$ filter (Millipore). Heavy metal concentrations before and after adsorption were measured by an atomic absorption spectrophotometer (Perkin Elmer 3300, USA). All adsorption experiments were performed in triplicate and means are reported.

\section{Results and Discussion}

\section{Surface Properties of UCRs}

Fig. 1 presents an SEM micrograph of UCRs, shows a surface morphology comprised of plates, likely with a small specific surface area. The specific surface area of UCRs was $0.19 \mathrm{~m}^{2} / \mathrm{g}$. This experimental result was similar to those obtained by Boonamnuayvitaya et al. [3] and Kyzas et al. [19], both of whom also reported that the surface area of UCRs was small. The surface potential of UCRs at $\mathrm{pH} 3$ and 5 was 21 and $-25 \mathrm{mV}$, respectively. These surface potentials were the same as those acquired by Franca et al. [20] and Kyzas et al. [19]. The pHzpc of UCRs was 3.9. At [adsorbate] $=20 \mathrm{mg} / \mathrm{L}, \mathrm{Pb}^{2+}$ and $\mathrm{Zn}^{2+}$ precipitated to $\mathrm{Pb}(\mathrm{OH})_{2}$ and $\mathrm{Zn}(\mathrm{OH})_{2}$ at $\mathrm{pH} 8.9$ and 7.1, respectively. Accordingly, $\mathrm{Pb}(\mathrm{OH})_{2}$ and $\mathrm{Zn}(\mathrm{OH})_{2}$ were not formed.

\section{Effects of Heavy Metal Concentration, UCRs Dosage, and Solution $\mathrm{pH}$ on Adsorption}

Fig. 2 presents the effects of $\mathrm{Pb}^{2+}$ concentration, UCR dosage, and solution $\mathrm{pH}$ on adsorption of $\mathrm{Pb}^{2+}$ by UCRs. Fig. 3 shows the effects of the $\mathrm{Zn}^{2+}$ concentration, UCR dosage, and solution $\mathrm{pH}$ on adsorption of $\mathrm{Zn}^{2+}$ by UCRs. After reaction for $180 \mathrm{~min}$ at [heavy metal] $=20 \mathrm{mg} / \mathrm{L}$, [UCRs] $=2 \mathrm{~g} / \mathrm{L}$, and $\mathrm{pH} 5$, the adsorption percentage of $\mathrm{Pb}^{2+}$ and $\mathrm{Zn}^{2+}$ was $96 \%$ and $44 \%$, respectively; moreover, the adsorption density of $\mathrm{Pb}^{2+}$ and $\mathrm{Zn}^{2+}$ onto UCRs was 9.7 and $4.4 \mathrm{mg} / \mathrm{g}\left(4.7 \times 10^{-2}\right.$ and $\left.6.8 \times 10^{-2} \mathrm{mmol} / \mathrm{g}\right)$, respectively. Both removal percentages for $\mathrm{Pb}^{2+}$ and $\mathrm{Zn}^{2+}$ increased as $\mathrm{pH}$ and UCR dose increased; conversely, they decreased as the $\mathrm{Pb}^{2+}$ and $\mathrm{Zn}^{2+}$ concentrations increased. Increasing the UCR dosage increased heavy metal adsorption. These experimental results were expected because as the UCR dose increased, the number of adsorption sites increased and the amount of adsorbate attached increased. At $\mathrm{pH} 5$ the surface charge of UCRs was negative; conversely, it was positive at $\mathrm{pH} 3$. Hence, the heavy metal removal percentage at $\mathrm{pH} 3$ was lower than that at $\mathrm{pH} 5$ because of electrical repulsion between cations and the positively charged surfaces of UCRs. Adsorption rate was rapid in the first $40 \mathrm{~min}$ of the reaction and then slowed; that is, the surface sites of UCRs were initially vacant and the heavy metal concentration gradient was relatively high. This rapid adsorption may be characterized as passive uptake through physical adsorption or adsorbent surface ion exchange $[1,21]$. The amount of heavy metal adsorbed per unit mass of UCRs $\left(\mathrm{q}_{\mathrm{e}}\right.$, exp. increased as $\mathrm{pH}$ and the heavy metal concentration increased; conversely, it decreased as UCR dosage increased (Table 1). This decrease in unit adsorption as the adsorbent dose increases was due to a large number of 
adsorption sites remaining unsaturated during the adsorption process. Several studies have also shown that unit adsorption capacity decreased as adsorbent dosage increased [2224]. This study found that the adsorption percentage and adsorption density $\left(\mathrm{q}_{\mathrm{e}, \text { exp }}\right.$ ) of $\mathrm{Pb}^{2+}$ was higher than that of $\mathrm{Zn}^{2+}$ under the same experimental conditions, suggesting that the affinity of $\mathrm{Pb}^{2+}$ for UCRs exceeded that of $\mathrm{Zn}^{2+}$.

\section{Analyses of Adsorption Kinetics}

Adsorption kinetics, which indicates the adsorption rate, is an important characteristic of adsorbents. The pseu- do first- and second-order models, the intraparticle diffusion model, and the Bangham model were adopted to test experimental data and thereby elucidate the kinetics of the adsorption process. The pseudo first-order model can be expressed as:

$$
\ln \left(q_{e}-q\right)=\ln \left(q_{e}\right)-k_{1} t
$$

...where $q_{e}$ and $q$ are the amounts of heavy metals adsorbed onto UCRs at equilibrium and at various times $t(\mathrm{mg} / \mathrm{g})$, respectively, and $k_{1}$ is the rate constant of the pseudo firstorder model of adsorption (1/min) [25]. The values of $q_{e}$

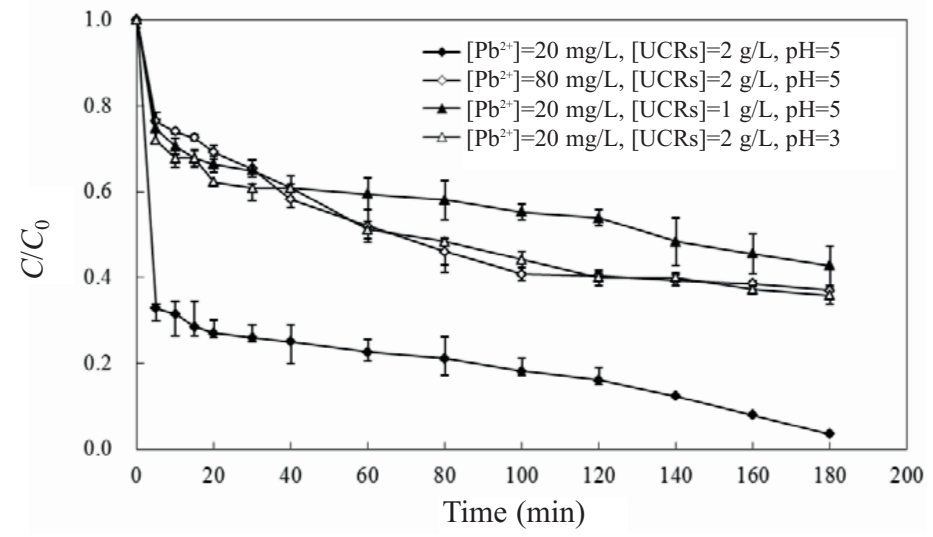

Fig. 2. Removal of $\mathrm{Pb}^{2+}$ according to $\mathrm{Pb}^{2+}$ concentration, UCR dose, and solution $\mathrm{pH}$.



Fig. 3. Removal of $\mathrm{Zn}^{2+}$ according to $\mathrm{Zn}^{2+}$ concentration, UCR dose, and solution $\mathrm{pH}$.

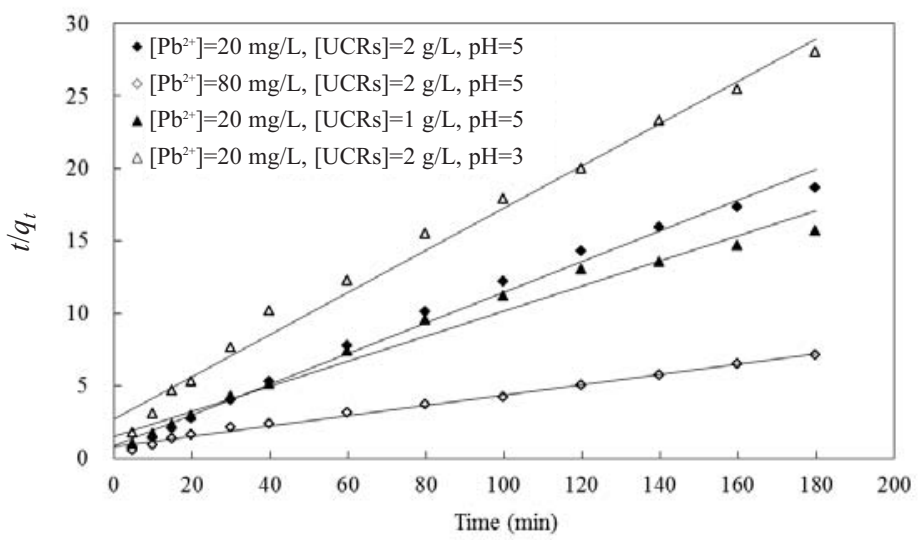

Fig. 4. Pseudo second-order adsorption kinetic plots of $\mathrm{Pb}^{2+}$ onto UCRs. 
Table 2. Calculations of the sum of the absolute errors for different models ([UCRs] $=2 \mathrm{~g} / \mathrm{L}$, [adsorbate $]=20 \mathrm{mg} / \mathrm{L}$ and $\mathrm{pH}=5$ )

\begin{tabular}{|l|c|c|}
\hline \multicolumn{1}{|c|}{$\mathrm{SAE}$} & $\mathrm{Pb}^{2+}$ & $\mathrm{Zn}^{2+}$ \\
\hline Pseudo first-order model & 3.89 & 1.78 \\
\hline Pseudo second-order model & 0.44 & 1.38 \\
\hline Intrapariticle diffusion model & 74.94 & 45.39 \\
\hline Bangham model & 4.50 & 5.35 \\
\hline
\end{tabular}

and $k_{1}$ can be derived from the intercept and slope of the linear plot of $\ln \left(q_{e}-q\right)$ versus $t$, respectively. The pseudo second-order model is:

$$
\frac{t}{q}=\frac{1}{k_{2} q_{e}^{2}}+\frac{t}{q_{e}}
$$

...where $q_{e}$ and $q$ are the amounts of heavy metals adsorbed onto UCRs at equilibrium and at various times $t$ $(\mathrm{mg} / \mathrm{g})$, respectively, and $k_{2}$ is the rate constant of the pseudo second-order model for adsorption $(\mathrm{g} / \mathrm{mg} \cdot \mathrm{min})$ $[26,27]$. The slope and intercept of the linear plot of $t / q$ as a function of $t$ yielded the values of $q_{e}$ and $k_{2}$, respectively. The adsorption process on porous adsorbents generally has four sequential stages: bulk diffusion, film diffusion, intraparticle diffusion, and adsorption of the adsorbate onto the surface of the adsorbent. Typically, bulk diffusion and adsorption are assumed to be rapid and, therefore, not rate determining. Since neither the pseudo firstorder nor the second-order model can identify the diffusion mechanism, kinetic results were analyzed using the intraparticle diffusion model to elucidate the diffusion mechanism. For the intraparticle diffusion model, film diffusion was negligible and intraparticle diffusion was the only rate-controlling step. The intraparticle diffusion model is expressed as:

$$
q=k_{i} t^{1 / 2}+C
$$

...where $C$ is the intercept and $k_{\mathrm{i}}$ is the intraparticle diffusion rate constant $\left(\mathrm{mg} / \mathrm{g} \cdot \mathrm{min}^{0.5}\right)$, which can be determined from the slope of the linear plot of $q$ versus $t^{1 / 2}$ [25]. Kinetic data were further utilized in this adsorption system based on the Bangham model [25]:

$$
\log \log \left(\frac{C_{0}}{C_{0}-q m}\right)=\log \left(\frac{k_{0} m}{2.303 V}\right)+\alpha \log (t)
$$

...where $q$ and $t$ are defined in the pseudo first-order model, $C_{0}$ is the initial heavy metal concentration in the solution $(\mathrm{mg} / \mathrm{L}), V$ is solution volume $(\mathrm{mL}), m$ is the mass of UCRs per liter of solution $(\mathrm{g} / \mathrm{L})$, and $k_{0}$ and $\alpha$ are constants.

The validity of these models was assessed by calculating the sum of absolute errors (SAE) using Eq. (5):

$$
S A E=\sum_{i=1}^{N}\left|q_{e, c a l}-q_{e, \text { means }}\right|_{i}
$$

...where subscripts "means" and "cal" denote experimental and calculated values, and $N$ is the number of data points.

Figs. 4 and 5 show the pseudo second-order adsorption kinetic plots of $\mathrm{Pb}^{2+}$ and $\mathrm{Zn}^{2+}$ onto UCRs, respectively. Table 1 presents the kinetic parameters for the removal of $\mathrm{Pb}^{2+}$ and $\mathrm{Zn}^{2+}$ by UCRs and Table 2 lists the sum of absolute errors for different models. For both the $\mathrm{Pb}^{2+}$ and $\mathrm{Zn}^{2+}$ adsorption processes, the calculated SAE values of the pseudo second-order model were smallest. Additionally, the $q$ value $\left(q_{e, \text { cal. }}\right)$ derived from the pseudo second-order model was in agreement with experimental $q$ values $\left(q_{e, \text { exp. }}\right)$, suggesting that the pseudo second-order model best represents adsorption kinetics (Table 1). Various researchers also have reported that adsorption kinetics followed the pseudo second-order model $[18,24,28]$. When the regression of $q$ versus $t^{1 / 2}$ is linear and passes through the origin, intraparticle diffusion is the sole rate-limiting step [25]. Although regression was linear, the plot did not pass through the origin (Table 1), indicating that adsorption merely involved intraparticle diffusion; that is, intraparticle diffusion was not the only rate-controlling step and other kinetic mechanisms controlled the adsorption rate. The double logarithmic plot using the Bangham equation yielded a good linear $\left(\mathrm{R}^{2}>0.92\right)$ for the removal of $\mathrm{Pb}^{2+}$ and $\mathrm{Zn}^{2+}$ by UCRs, indicating that the diffusion of heavy metal into UCR pores is not the only rate-controlling step [29]. Akkaya et al. [30]

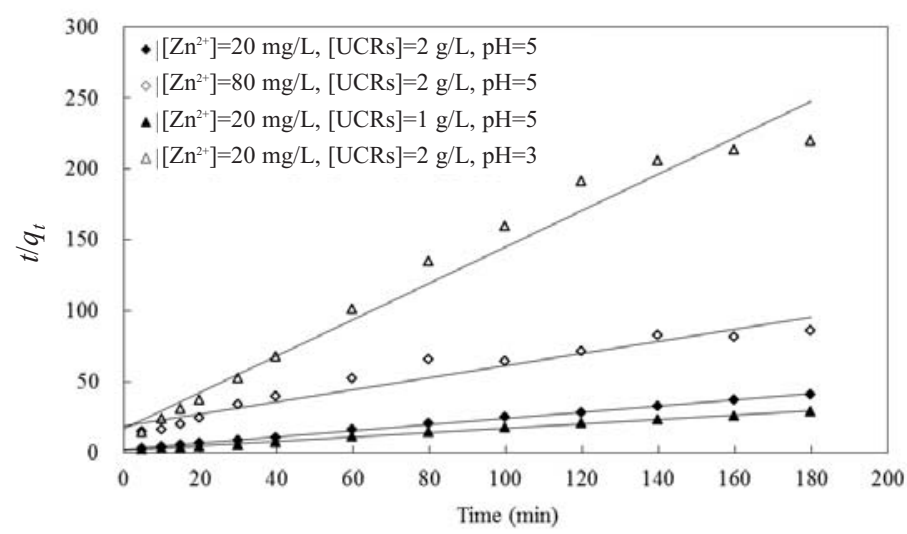

Fig. 5. Pseudo second-order adsorption kinetic plots of $\mathrm{Zn}^{2+}$ onto UCRs. 
demonstrated that pore diffusion and surface diffusion are simultaneous within an adsorbent particle. Since the BET surface area of UCRs is very small, study results suggest that adsorption kinetics were controlled mainly by surface diffusion.

\section{Comparisons of $\mathrm{Pb}^{2+}$ and $\mathrm{Zn}^{2+}$}

The hydration enthalpy of metal ions can be applied to assess the theoretical affinity of metal ions for adsorbents. Hydration enthalpy corresponds to the energy that permits detachment of water molecules from metal ions and also reflects the ease with which one ion interacts with a ligand located on the surface of UCRs. As the hydration of a metal ion increases, the strength of metal hydration increases, such that the likelihood that the metal ion will interact with a ligand declines [31]. Martin-Dupont et al. [31] indicated the hydration enthalpy of $\mathrm{Pb}^{2+}$ and $\mathrm{Zn}^{2+}$ was -1481 and $2046 \mathrm{~kJ} / \mathrm{mol}$, respectively; accordingly, the theoretical affinity of $\mathrm{Pb}^{2+}$ and $\mathrm{Zn}^{2+}$ for a ligand follows the order $\mathrm{Pb}^{2+}>$ $\mathrm{Zn}^{2+}$. The theoretical affinity order is in agreement with experimental results and those of several previous studies $[3,5,6,31]$, which also found that the adsorption affinity of $\mathrm{Pb}^{2+}$ was greater than that of $\mathrm{Zn}^{2+}$ for biosorbents.

\section{Conclusions}

The adsorption kinetics of $\mathrm{Pb}^{2+}$ and $\mathrm{Zn}^{2+}$ onto UCRs were examined. Metal ions adsorbed per unit mass of UCRs increased as $\mathrm{pH}$ and the concentration of metal ions increased; conversely, it decreased as the UCR dosage increased. Based on SAE and adsorption density, the pseudo second-order model best represents adsorption kinetics. The adsorption kinetics are controlled mainly by surface diffusion according to analyses of the intraparticle diffusion model and Bangham model. Maximum adsorption onto UCRs followed the order $\mathrm{Pb}^{2+}>\mathrm{Zn}^{2+}$, which agreed with theoretical analyses for hydration enthalpy of $\mathrm{Pb}^{2+}$ and $\mathrm{Zn}^{2+}$.

\section{Acknowledgements}

The authors would like to thank the National Science Council of the Republic of China, Taiwan, for financially supporting this research under Contract No. NSC 1012221-E-151-038-MY3.

\section{References}

1. LI X., TANG Y., CAO X., LU D., LUO F., SHAO W. Preparation and evaluation of orange peel cellulose adsorbents for effective removal of cadmium, zinc, cobalt and nickel. Colloids Surf. A. 317, 512, 2008.

2. OLIVEIRA W.E., FRANCA A.S., OLIVEIRA L.S., ROCHA S.D. Untreated coffee husks as biosorbents for the removal of heavy metals from aqueous solutions. J. Hazard. Mater. 152, 1073, 2008.
3. BOOMAMNUAYVITAYA V., CHAIYA C., TANTHAPANICHAKOON W. Removal of heavy metals by adsorbent prepared from pyrolyzed coffee residues and clay. Sep. Purif. Technol. 35, 11, 2004.

4. UTOMO H.D., HUNTER K.A. Adsorption of divalent copper, zinc, cadmium and lead ions from aqueous solution by waste tea and coffee adsorbents. Environ. Technol. 27, 25, 2006.

5. UTOMO H.D., HUNTER K.A. Particle concentration effect: Adsorption of divalent metal ions on coffee grounds. Bioresour. Technol. 101, 1482, 2010.

6. REDDAD Z., GERENTE C., ANDRES Y., CLOIREC P.L. Adsorption of several metal ions onto a low-cost biosorbent: Kinetic and equilibrium studies. Environ. Sci. Technol. 36, 2067, 2002.

7. AHLUWALIA S.S., GOYAL D. Removal of heavy metals by waste tea leaves from aqueous solution. Eng. Life Sci. 5, 158, 2005.

8. ASADI F., SHARIATMADARI H., MIRGHAFFARI N. Modification of rice hull and sawdust sorptive characteristics for remove heavy metals from synthetic solutions and wastewater. J. Hazard. Mater. 154, 451, 2008.

9. XIAO J., ZHAO L., ZHANG W., LIU X., CHEN Y. Effect of $\mathrm{pH}$, ionic strength, foreign ions, humic acid and temperature on $\mathrm{Zn}(\mathrm{II})$ sorption onto $\gamma-\mathrm{Al}_{5} \mathrm{O}_{3}$. Korean J. Chem. Eng. 31, 253, 2014.

10. MUSTAFA S., IRSHAD M., WASEEM M., SHAH K.H., RASHID U., REHMAN W. Adsorption of heavy metal ions in ternary systems onto $\mathrm{Fe}(\mathrm{OH})_{3}$. Korean J. Chem. Eng. 30, 2235, 2013

11. SAEED A., IQBAL M., AKHTAR M.W. Removal and recovery of lead(II) from single and multimetal $(\mathrm{Cd}, \mathrm{Cu}, \mathrm{Ni}$, $\mathrm{Zn)}$ solutions by crop milling waste (black gram husk). J. Hazard. Mater. 117, 65, 2005.

12. TOKIMOTO T., KAWASAKI N., NAKAMURA T., AKUTAGAWA J., TANADA S. Removal of lead ions in drinking water by coffee grounds as vegetable biomass. J. Colloid Interface Sci. 281, 56, 2005.

13. AMARASINGHE B.M.W.B.K., WILLIAMS R.A. Tea waste as a low cost adsorbent for the removal of $\mathrm{Cu}$ and $\mathrm{Pb}$ from wastewater. Chem. Eng. J. 132, 299, 2007.

14. FENG Q., LIN Q., GONG F., SUGITA S., SHOYA M. Adsorption of lead and mercury by rice husk ash. J. Colloid Interface Sci. 278, 1, 2004.

15. MARTINEZ M., MIRALLES N., HIDALGO S., FIOL N., VILLAESCUSA I., POCH J. Removal of $\mathrm{Pb}$ (II) and cadmium(II) from aqueous solutions using grape stalk waste. J. Hazard. Mater. 133, 203, 2006.

16. ROH H.G., KIM S.G., JUNG J. Adsorption of heavy-metal ions $\left(\mathrm{Pb}^{2+}, \mathrm{Cu}^{2+}\right)$ on perm-lotion-treated human hair. Korean J. Chem. Eng. 31, 310, 2014.

17. ESCUDERO C., GABALDON C., MARZAL P., VILLAESCUSA I. Effect of EDTA on divalent metal adsorption onto grape stalk and exhausted coffee wastes. J. Hazard. Mater. 152, 476, 2008.

18. AZOUAOU N., SADAOUIA Z., DJAAFRI A., MOKADDEM H. Adsorption of cadmium from aqueous solution onto untreated coffee grounds: Equilibrium, kinetics and thermodynamics. J. Hazard. Mater. 184, 126, 2010

19. KYZAS G.Z., LAZARIDIS N.K., MITROPOULOS A.Ch. Removal of dyes from aqueous solutions with untreated coffee residues as potential low-cost adsorbents: Equilibrium, reuse and thermodynamic approach. Chem. Eng. J. 189-190, 148, 2012.

20. FRANCA A.S., OLIVEIRA L.S., FERREIRA M.E. Kinetics and equilibrium studies of methylene blue adsorption by spent coffee grounds. Desalination 249, 267, 2009. 
21. TING Y.P., LAWSON F., PRINCE I.G. Uptake of cadmium and zinc by the alga Chlorella vulgaris: part I. Individual ion species. Biotechnol. Bioeng. 34, 990, 1989.

22. LATA H., GARG V.K., GUPTA R.K. Adsorptive removal of basic dye by chemically activated Parthenium biomass: equilibrium and kinetic modeling. Desalination 219, 250, 2008.

23. PONNUSAMI V., VIKRAM S., SRIVASTAVA S.N. Guava (Psidium guajava) leaf powder: novel adsorbent for removal of methylene blue from aqueous solutions. J. Hazard. Mater. 152, 276, 2008.

24. FRANCA A.S., OLIVEIRA L.S., NUNES A.A., ALVES C.C.O. Microwave assisted thermal treatment of defective coffee beans press cake for the production of adsorbents. Bioresour. Technol. 101, 1068, 2010.

25. MALL I.D., SRIVASTAVA V.C., AGARWAL N.K. Removal of orange-G and methyl violet dyes by adsorption onto bagasse fly ash - kinetic study and equilibrium isotherm analyses. Dyes Pigm. 69, 210, 2006.
26. BLANCHARD G., MAUNAYE M., MARTIN G. Removal of heavy metals from waters by means of natural zeolites. Water Res. 18, 1501, 1984.

27. HO Y.S., MCKAY G. Pseudo-second order model for sorption processes. Process Biochem. 34, 451, 1999.

28. HAN R., ZHANG L., SONG C., ZHANG M., ZHU H., ZHANG L. Characterization of modified wheat straw, kinetic and equilibrium study about copper ion and methylene blue adsorption in batch mode. Carbohyd. Polym. 79, 1140, 2010.

29. KAVITHA D., NAMASIVAYAM C. Recycling coir pith, an agricultural solid waste, for the removal of procion orange from wastewater. Dyes Pigm. 74, 237, 2007.

30. AKKAYA G., UZUN I., GUZEL F. Kinetics of the adsorption of reactive dyes by chitin. Dyes Pigm. 73, 168, 2007.

31. MARTIN-DUPONT F., GLOAGUEN V., GRANET R., GUILLOTON M., MORVAN H., KRAUSZ P. Heavy metal adsorption by crude coniferous barks: A modelling study. J. Environ. Si. Health A 37, 1063, 2002. 
